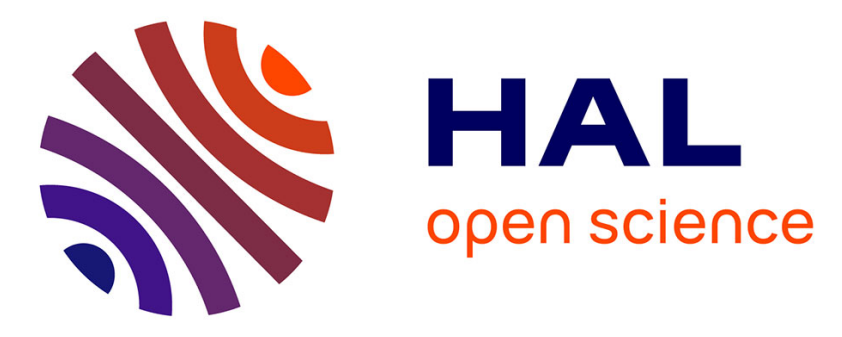

\title{
Humusica 1, article 1: Essential bases - Vocabulary
} Augusto Zanella, Jean-François Ponge, Jean-Michel Gobat, Jérôme Juilleret, Manuel Blouin, Michaël Aubert, Oleg Chertov, José Luis Rubio

\section{To cite this version:}

Augusto Zanella, Jean-François Ponge, Jean-Michel Gobat, Jérôme Juilleret, Manuel Blouin, et al.. Humusica 1, article 1: Essential bases - Vocabulary. Applied Soil Ecology, 2018, 122 (Part 1), pp.1021. 10.1016/j.apsoil.2017.07.004 . hal-01660760

\section{HAL Id: hal-01660760 https://hal.science/hal-01660760}

Submitted on 11 Dec 2017

HAL is a multi-disciplinary open access archive for the deposit and dissemination of scientific research documents, whether they are published or not. The documents may come from teaching and research institutions in France or abroad, or from public or private research centers.
L'archive ouverte pluridisciplinaire HAL, est destinée au dépôt et à la diffusion de documents scientifiques de niveau recherche, publiés ou non, émanant des établissements d'enseignement et de recherche français ou étrangers, des laboratoires publics ou privés. 


\section{Humusica 1, article 1: Essential bases - Vocabulary}

Augusto Zanella ${ }^{\mathrm{a},{ }^{\dagger}}$, Jean-François Ponge ${ }^{\mathrm{b}}$, Jean-Michel Gobat ${ }^{\mathrm{c}}$, Jérôme Juilleret ${ }^{\mathrm{d}}$, Manuel Blouin ${ }^{\mathrm{e}}$, Michaël Aubert ${ }^{f}$, Oleg Chertov ${ }^{g}$, José Luis Rubio ${ }^{h}$

${ }^{a}$ University of Padua, Italy

${ }^{\mathrm{b}}$ Muséum National d'Histoire Naturelle, Paris, France

${ }^{\mathrm{c}}$ Université de Neuchâtel, Switzerland

${ }^{\mathrm{d}}$ Luxembourg Institute of Science and Technology, Belvaux, Luxembourg

${ }^{\mathrm{e}}$ AgroSup, Dijon, France

${ }^{\mathrm{f}}$ Normandie Université, Rouen, France

${ }^{\mathrm{g}}$ University of Applied Sciences, Bingen, Germany

${ }^{\mathrm{h}}$ University of Valencia, Spain

Keywords: Humus; Humusica; Humus form classification; Humus system; Humus vocabulary; Soil classification; Soil concept

\section{ABSTRACT}

The Special Issue Humusica 1 corresponds to a field guide for the classification of terrestrial humus systems and forms. The present first article of the issue defines vocabulary, objects and concepts necessary for: (a) field investigation, (b) understanding the process of classification, (c) assigning ecological significance to the defined morpho-functional units, (d) discussing and exchanging scientific data about humus systems. The article starts with general considerations, as the necessity humans have to classify natural objects for sharing ideas and information on them. Then the article focuses on soil as functional element of every ecosystem. Historical and recently published international definitions of soil are reported and compared to the more biological definition of the authors of the paper. Once the concept "soil" is clarified, the soil profile is shared in three new subunits, for further specialised investigations. The superficial and organic-rich sub-unit is labelled Humipedon. In the rest of the article, authors explain the different constituents of a general humipedon, introducing even novice soil scientists to field practice and topsoil observation. A general overview of the variety of humipedons that one may expect to find all over planet Earth, classified in humus systems and forms, concludes the article.

\footnotetext{
${ }^{*}$ Music while reading? Light in Babylon - Hinech Yafa - Istanbul: https://www.youtube.com/watch?v=aKJvbTEnpOlor; National Chamber orchestra of Armenia: Vivaldi - Gloria: https://www.youtube.com/watch?v=RMHguvZPcqQ

${ }^{\dagger}$ Corresponding author.

E-mail address: augusto.zanella@unipd.it (A. Zanella).
} 


\section{Why do we classify things?}

To classify objects is no longer in fashion, even if the modern natural science is based on a genial Darwinian observation and classification of living organisms. We cannot understand the soil functioning without imitating Darwin and observing/classifying living soil profiles as if they were living systems. We always need to compare at least two objects or concepts for understanding the world in which we stay and act. We are richer or poorer than our next-door neighbour; we cannot be rich or poor in absolute. The same for knowledge, we cannot know everything, we have got a certain amount of information but we cannot know how much it is worth in absolute. We probably have more knowledge about soil than our family doctor, but we cannot say how much we know about soil in absolute. The only mean we have to estimate the quality of our knowledge is to compare it with a given state-of-the-art, and this in each given domain. If we fix a starting point, a point of shared knowledge, then we can compare our state with this reference. We call this process "classification". Some examples of historical useful "morpho-functional" classification: (a) we know that sunlight is white and that it is made of the rainbow colours we are able to see with our eyes (this is how we understand something still unknown we call light); (b) we know that matter is made of atoms, and that atoms are made of particles themselves made in turn of other particles (each of these assemblages displaying its own emergent properties; applications to natural phenomena in Zanella, 1994; Ponge, 2005; deep review in Humusica 1, article 2); (c) starting points, basic limits: (1) when water becomes ice, the temperature of the water bath is $0^{\circ} \mathrm{C}$; when water is boiling, it has a temperature of $100^{\circ} \mathrm{C}$; (2) our body temperature when in good health is $37^{\circ} \mathrm{C} ;(3)$ time also is measured in comparison with our heart bit: one bit, one second, 60 bits one minute and 60 min one hour. For understanding the complex dynamic processes that occur at the level of soil, we need to classify some crucial elemental soil components, and circumscribe as real as possible functional soil sub-systems.

Imitating these examples and wanting to study soil biology and functioning, we coined some "starting referential objects and concepts" and described them in the following pages. With these notions in mind, going to the field and "reading" the soil as a "page of nature" is quite a pushover (sections 4-6 of this article). It is also easier to compare different topsoils (then called "Humipedons") and understand how they function and provide services, each soil with specific attitudes, in harmony with the sustained ecosystems.

\section{What's soil?}

Let us consider official definitions first:

a) Soil is organic or lithic material at the surface of planets and similar bodies altered by biological, chemical, and/or physical agents (Johnson, 1998).

b) Soil in "Soil Science Glossary 2008" (GSST, 2008): (i) The unconsolidated mineral or organic material on the immediate surface of the earth that serves as a natural medium for the growth of 
land plants. (ii) The unconsolidated mineral or organic matter on the surface of the earth that has been subjected to and shows effects of genetic and environmental factors of: climate (including water and temperature effects), and macro- and microorganisms, conditioned by relief, acting on parent material over a period of time. A product-soil differs from the material from which it is derived in many physical, chemical, biological, and morphological properties and characteristics.

c) Solum in "Wikipedia", https://en.wikipedia.org/wiki/Solum: the solum (plural, sola) in soil science consists of the surface and subsoil layers that have undergone the same soil-forming conditions. The base of the solum is the relatively unweathered parent material. Solum and soils are not synonymous. Some soils include layers that are not affected by soil formation. These layers are not part of the solum. The number of genetic horizons ranges from one to many. A surface layer that is $10 \mathrm{~cm}$ thick overlying bedrock can be by itself the solum. A soil that consists only of recently deposited alluvium or recently exposed soft sediment does not have a solum. In terms of soil horizon designations, a solum consists of $A, E$, and $B$ horizons and their transitional horizons and some $\mathrm{O}$ horizons. Included are horizons with an accumulation of carbonates or more soluble salts if they are either within, or contiguous, to other genetic horizons and are at least partly produced in the same period of soil formation. The solum of a soil presently at the surface, for example, includes all horizons now forming. The solum of a soil is not necessarily confined to the zone of major biological activity. A solum does not have a maximum or a minimum thickness. The lower limit should relate to the depth of rooting to be expected for perennial plants, assuming that soil moisture conditions and soil chemistry are not limiting.

Note: this definition, downloaded in November 2016, has been removed from Wikipedia. Some "hot matter" was present in the definition. Examples: "Solum and soils are not synonymous. Some soils include layers that are not affected by soil formation. These layers are not part of the solum"; or: "A soil that consists only of recently deposited alluvium or recently exposed soft sediment does not have a solum"; or "The lower limit should relate to the depth of rooting to be expected for perennial plants assuming that soil moisture conditions and soil chemistry are not limiting".... Written by a soil scientist (who stated that "Included are horizons with an accumulation of carbonates or more soluble salts if they are either within, or contiguous, to other genetic horizons and are at least partly produced in the same period of soil formation"), this definition expresses the uneasy felt by many soil scientists for parts of a soil definition. Other examples of simplified definitions are available online (for instance: Plant \& Soil Sciences eLibraryPRO:

http://passel.unl.edu/pages/informationmodule.php?idinformationmodule=1130447025\&topicorder $=4)$.

d) A curious, last published "centimetric" definition: Soil is a centimetric or thicker unconsolidated layer of fine-grained mineral and/or organic material, with or without coarse elements and cemented portions, lying at or near the surface of planets, moons, and asteroids, which shows clear evidence of chemical weathering (Certini and Ugolini, 2013).

e) Soil in "Keys to Soil Taxonomy" (Soil Survey Staff, 2014) is a natural body comprised of solids (minerals and organic matter), liquids, and gases that occurs on the land surface, occupies space, and is characterized by one or both of the following: horizons, or layers, that are distinguishable from the initial material as a result of additions, losses, transfers, and transformations of energy and matter or the ability to support rooted plants in a natural environment (Soil Survey 
Staff, 1999). This definition is expanded from the previous version of Soil Taxonomy (Soil Survey Staff, 1975) to include soils in areas of Antarctica where pedogenesis occurs but where the climate is too harsh to support higher plant forms. Commonly, soil grades at its lower boundary to hard rock or to earthy materials virtually devoid of animals, roots, or other marks of biological activity. The lowest depth of biological activity, however, is difficult to discern and is often gradual. For the practicability of soil survey, the lower boundary of soil is arbitrarily set at $200 \mathrm{~cm}$.

f) Soil classified in the "World Reference Base for Soil Resources" (IUSS Working Group WRB, 2015) is: any material within $2 \mathrm{~m}$ of the Earth's surface that is in contact with the atmosphere, excluding living organisms, areas with continuous ice not covered by other material, and water bodies deeper than $2 \mathrm{~m}$. If explicitly stated, the object classified in the WRB includes layers deeper than $2 \mathrm{~m}$.

g) Soils are the thin layer covering our Earth planet. They are complex blends of living and mineral materials. Just like birds or plants there are thousands of kinds of soil. Soil is a vital natural resource, it filters and stores water, and is an important part of the Earth system. Most of our food comes from cultivated soils (Hartemink, 2016).

h) Definition of the soil given by the authors of this article: The soil corresponds to a biological cover spread all over our planet and corresponding to a huge "digestive and accumulative system" fed by organic and/or mineral compounds. When dismantled, structured mineral and organic matters deliver energy and bricks for new living structures. The organic matter stored in the soil, namely humus, serves as a stabilizing factor for terrestrial ecosystems due to sequestered elements and optimized soil environment, and also soil organic matter is an initial stage of carbon fossilization in the Earth crust resulting in the formation of fossil energy sources. The biological processes of demolition, selection, storage, reapplication of energy and building material from transformed mineral and organic matters occur in every living organism. They take place in the "soil" when an external support is required for implementing new living functional units. The evolution of life on Earth, expressed in increasingly complex natural ecosystems, is realized by breaking down mineral and organic structures and using the resulting elemental pieces and energy for assembling new organisms in new habitats and ecosystems. At the base of this living pyramid, there is a soil collecting and recycling remnants of the generated functional units. Have we humans a little soil in our belly? $?^{\ddagger}$ Are we also a soil-depending natural system that has simply grown around a biologically controlled soil? Whatever the answer, a soil system is mandatory to sustain the functioning of each existing universal ecosystem. The soil on the Earth comprehends the upper part of the planet crust inhabited by living organisms. It is made of organic, organic-mineral and mineral layers, comprising fresh litter at the top and altered hard rock at the bottom. The soil (Humi-, Co- and Lithopedon) is connected to the space (Cosmopedon, in Humusica 2, article 13), it flies (Aeropedon) and swims (Hydropedon), sleeps in the rocks (Geopedon) and inhabits even living organisms (Symbiopedon).

\section{What's humus in the soil?}

\footnotetext{
${ }^{\ddagger}$ Gut content in us is a derivate of organic soil but without accumulative function. Accumulation takes pace in our tissues. So gut content is a soil, and we ourselves are a derivate of nutrient-consuming plants (Ugolev, 1991).
} 
"Humus" is a Latin name of Greek origin, meaning "earth, ground, soil", sharing the same Indio-European root than "Homo" (Humans), which was introduced in soil science at the end of the $18^{\text {th }}$ century for designating any kind of soil organic matter without any recognizable plant structure. This is a strictly chemical sense, which was used mainly by soil analysts when trying to desperately separate it from what they called "raw" organic matter. Thorough microscopic investigations made by Bernier and Ponge (1994) showed that well-humified "amorphous" organic matter is mostly made of plant and microbial remains still recognizable under the light microscope, and thus that the frontier between "raw" organic matter" and "humus" is largely illusory and outdated (Stevenson, 1972, 1994). The sense of "humus" has been enlarged to include any part of the soil where organic matter is present, whatever its chemical form is. It is commonly used in the absence of any analytical method for designating any type of dead and transformed organic matter, whether on the ground or in aboveground environments such as flowerpots, green roofs, epiphytic rooting media. However, far from being dead, humus is the seat of an abundant life, embracing subterranean parts of plants (roots, rhizomes, tubers), microbes (fungi, bacteria, archaea, micro-algae) and animals (from invertebrates to vertebrates), making it the largest known reservoir of biodiversity (Brussaard, 1997).

In the topsoil the recycling of dead organs or organisms takes place (Ponge, 2003). Old structures decompose and their parts are transformed or eaten by living organisms (Ponge, 1991), which generates new structures (Fig. 1a, purposely philosophic: humans are part of the soil cycle, genetically speaking, too, human DNA of buried people is recycled. Examples of surging questions: could it be that a generalized practice of body incineration may influence the natural evolution? In cremated remains, DNA can only be obtained from bone fragments or teeth:

https://privatelabresults.com/cremated-remains-dna-\%20testing/).

Humus functioning can be summarized in seven steps:

1) structures of any living system have a limited time of efficient activity. Generally everything becomes less "valid" as time goes by and finally has to be replaced (=dies);

2) the process of replacement is known under the name of "decomposition". In the soil, during decomposition, dead structures deliver little by little their energy and constitutional bricks which accumulate as such in the topsoil or are transformed (recycled, reworked) by organisms;

3) water, bioturbation (physical disturbance by burrowing organisms) and ingestion (feeding by soil-eating animals) transport these organic pieces and put them in contact with mineral elements; a stable interaction occurs between mineral and organic soil components;

4) living organisms (micro-, meso-, macro-organisms) inhabit the soil and use this source of energy and nutrients for their own development, movement and reproduction;

5) as a consequence of these biological and physical-chemical activities, which are vertically stratified (influenced by organic matter at the top, and by mineral matter at the bottom), the soil structures itself in layers; the series of layers and their contents (e.g., molecules, aggregates, over-structures, organisms) is called "soil";

6) all the terrestrial surface of our planet is covered with soils. They change in space and time following the dynamics of the ecosystems in which they develop; 


\section{The pedon, a "sample of soil"}

Pedon. If we want to study the soil and carry "pieces" of soil in a laboratory, we need to delimitate in the field one of these units of soil (Fig. 1b). According to Van Wambeke (1966), an ideal basic unit for soil classification should: (a) be an object which is observable and measurable in three dimensions and includes the whole vertical thickness of the soil; (b) be independent of all taxonomic systems; (c) have clear boundaries, although arbitrarily fixed; and (d) be of a size convenient for study, measurement and sampling. The term pedon copes with these needs and has been proposed as a collective name for small basic soil entities (Soil Survey Staff, 1960; Simonson and Gardner, 1960). The original definition of pedon with the historical meanings that converged in this concept can be read in Norman (1968, page 37): "A pedon consists of a small volume of soil which includes the full solum and the upper part of the unconsolidated parent material (or a volume of comparable size if horizons are faint), is usually less than 2 meters in depth, and between 1 and 10 square meters in size. The smallest of these lateral dimensions is proposed for use in most soils."

The soil has a top part richer in organic matter and living organisms, called "Humipedon". Here down, the origin of this appellation.

Trying to give to the word "pedon" even a more practical sense, we can write that a pedon consists in the smallest body of one kind of soil, large enough to represent the nature and arrangement of horizons and soil properties to be preserved in samples. Hence, it is a volume of soil of variable dimension, (commonly $100 \times 100 \times 100 \mathrm{~cm}$ ), representing a soil type (Fig. 1b). OL, ${ }^{\S} \mathrm{HF}^{* *}$ horizons and the $\mathrm{R}^{+\dagger}$ layer are sometimes considered original components and not "generated soil", i.e. not real "soil".

Fallen leaves and dead organisms are very different from photosynthesizing leaves and active organisms, and may be considered soil by soil scientists (Ponge, 2015); the upper part of a parent material, even if rocky, is also more or less altered and may be considered soil, too. Because of this ambiguity, in Figures $2 a$ and $b$ the edges of the pedon are represented by dashed lines. Generally, the pedon is placed in the middle of a site homogeneous in terms of vegetation, parent material and topography, or homogeneous at the ground surface, hoping the best for what cannot be seen belowground (AFES, 2009). The homogeneity is tested all around with a manual auger, detecting the same series of horizons on the four vertical sides of the soil column.

\footnotetext{
$\S$ OL: O= organic =at least weight $20 \%$ of organic carbon in dry samples, without living roots (Method: elementary analyser, ISO 10694, 1995); L =not or poorly decomposed organic material (IUSS Working Group WRB, 2006; Soil Survey Staff, 2014) = humic component amounts to less than $10 \%$ by volume; recognizable remains $10 \%$ and more, up to $100 \%$ in undecomposed litter (Zanella et al., $2011 \mathrm{~b}$ ).

${ }^{* *} \mathrm{H}$ : horizons dominated by organic material formed from the accumulation of undecomposed or partially decomposed organic material at the soil surface, which may be underwater (IUSS Working Group WRB, 2006), $\mathrm{HF}=$ histic organic horizon consisting almost entirely of practically unchanged plant remains. Fibric component $\geq 90 \%$, sapric component « 10\% of horizon volume. Content of rubbed fibres (Lévesque and Dinel, 1977; Lévesque et al., 1980; Green et al., 1993) $\geq 40 \%$ of soil by dry weight $\left(105^{\circ} \mathrm{C}\right)$.

${ }^{++} \mathrm{R}$ : hard bedrock underlying the soil (IUSS Working Group WRB, 2006; Soil Survey Staff, 2014).
} 
Soil profile. One of the four sides of a pedon is called soil profile and is visible when opening a hole in the soil or cleaning an escarpment. In a pedon, soil horizons are generally grouped in three sections (Fig. 2).

In this issue, we propose specific new names for these sections (Fig. 2a-c).

Humipedon (Greek Humus, earth, soil, and pedon, sample of soil). Part of the soil in contact with light and either atmosphere or water body where dead organic matter either accumulates and/or is mixed with mineral matter by bioturbation and/or percolation processes (Fig. 3). As dead organic matter comes from above- and belowground plants and animals, the input of dead organic matter is dynamic in space and time either at plot or macro-scale. In submerged circumstances, the Humipedon can be formed by accumulation of dead organic material, developing Histic organic horizons (HF, HM, HS) or mixed organic-mineral horizons (anA ${ }^{\ddagger \ddagger}$ anaA ${ }^{\S \S}$, anaOA). In Humusica 2, articles $9,10,12$ and 13, we reported standard definitions of these horizons with numerous figures. In terrestrial conditions, under favourable circumstances, bioturbation by flora and fauna dominate and the Humipedon presents a double and sensitive composition made of organic and organicmineral materials. The organic material (O horizons, OC $\gg 20 \%$ ) can be made of recognizable remains (details and photographs in Humusica 1, article 4) or humic component (which can be organic or rich in C organic-mineral material; details in article 4); the organic-mineral material (OC $\leq$ $20 \%)$ is made of aggregates forming $A$ horizons $\left(A^{* * *}\right)$.

Depending on season, new litter (new OL and HF) could be present or not and corresponds to aboveground organic matter that periodically feeds the soil, disappearing during the processes of biodegradation and incorporation in the underlying soil horizons. The dynamic process of biodegradation transforms $\mathrm{OL}, \mathrm{HF}$ and decants organic and mineral matter in underlying soil horizons, feeding the life of the sustained ecosystems. Processes of biodegradation and incorporation of organic matter in the underlying mineral soil have a time range from a few days (in very active tropical habitats) to millenaries (in submerged habitats). Finally, an environmentdepending succession of dynamic horizons (Terrestrial: OL - OF - OH - A, or Histic: HF - HM - HSanA, or Aqueous: anaOA, anaA) characterizes each particular Humipedon. At the Humipedon level, $\mathrm{OL}$ and $\mathrm{HF}$ horizons are always measured and investigated (this is not the case in all soil

\footnotetext{
¥‡ anA: A of Anmoor. Histic organo-mineral horizon mostly formed by microorganisms (actinomycetes), darkcoloured, with plastic and massive structure, either high or low base-saturated.

$\S \S$ anaOA [ana =anaerobic, from Greek an (without), aer (air) and bios (life)] = organic and/or organic-mineral horizon formed by the deposition of organic and mineral particles suspended in water. Never emerged OA horizon. Plant roots possible (seagrasses). First phases of biological formation of sea and ocean floors, river beds. They can show even zoological activity due to benthic organisms (crustaceans, molluscs and aquatic worms). anaA [ana= anaerobic, from Greek an (without), aer (air) and bios (life)] = organic-mineral horizon formed by the deposition and transformation of organic and mineral particles suspended in water. Never emerged A horizon. Plant roots possible (seagrasses). Iron oxides always in reduced greyish/greenish form $\left(\mathrm{Fe}_{2} \mathrm{O}_{3}\right)$. Slow process of anaerobic biotransformation of organic matter in place. They can show zoological activity due to benthic organisms (crustaceans, molluscs and aquatic worms). When the volume of mineral particles estimated by the naked eye in fresh samples is larger than $90 \%$ of the horizon volume, the horizon is labelled anaAC. Generated by the evolution of an anaOA horizon. Sea and ocean floors, large river beds. ${ }_{* * *}$ A: Organic-mineral horizon formed near the soil surface, generally beneath organic horizons. Coloured by organic matter, this horizon is generally darker than the underlying mineral layer of the soil profile. In the $<2$ $\mathrm{mm}$ soil fraction of the A horizon, organic carbon has to be less than $20 \%$ by mass (Method: elementary analyser, ISO 10694, 1995).
} 
investigations and classifications). This very biologically active part of the pedon is the more sensitive to erosion and sedimentation processes (Fig. 3).

Copedon (Co, from Latin, reduced form of commit, com-, with, together, in association, and pedon, soil). Part of the soil characterized by a dominant mineral material showing soil aggregate structures in most of the volume of the fine earth fraction. In average, its organic carbon content is less than half the amount estimated in the above A horizon. The soil structure combines zoogenic rounded aggregates and non zoogenic (often polyhedral) aggregates. However some Copedons, more influenced by textural and structural characteristics of the Lithopedon, show a massive or single-grain structure. The Copedon generally corresponds to $B$ and $E$ horizons.

Lithopedon (Gr. Lithos, stone and pedon, soil). Part of the soil where rock structure dominates $(\geq 50 \%)$ and soil structure (aggregates) generated by pedogenetic processes represents < $90 \%$ of the volume of the fine earth fraction. The Lithopedon corresponds to $C$ and $R$ layers of the pedon, dominated in volume by slightly altered to unaltered rocks and/or coarse elements, and/or fine-grained mineral material. Enhancing the physicochemical weathering of minerals, the Lithopedon has a negligible content in organic matter even if the influence of organisms (bacteria, roots) plays a fundamental role in mineral weathering processes. It feeds in minerals and capillary water the overlying plant-soil ecosystem and could be seen as a second interface, lying at the bottom of the soil and supplying it in new mineral elements.

Rather than being shared, these parts of pedons often intermingle in each other (Fig. 2c) and the transitions between them are often gradual and wavy. As in a process of concomitant speciation and subdivision, they are submitted to opposing forces: on one hand they are pushed toward a higher specialization, forming three distinct functional parts of a shared soil profile; on the other hand they tend to form a single main entity, a single functional soil profile (Fig. 2c).

\section{One soil, many functional units}

Since many years, organisms are recognized as important factors of soil formation (Darwin, 1881; Jenny, 1941). Soil is increasingly recognized as a living entity (Sugden et al., 2004; Gobat et al., 2010; Ritz and Young, 2011). However, soil scientists have mainly studied soil for its physicalchemical properties. Even soil ecologists did not look at soil from the view point of the main biological theory: evolution (Barot et al., 2007). In recent years, ecology and evolution became each other closer, with the recognition that time scales of ecological and evolutionary processes can fit together and the concept of ecological inheritance emerged (Bonduriansky and Day, 2009; OdlingSmee et al., 2013; Nikol'skii, 2014). Organism-mediated environmental modifications can persist through time and affect selection pressures experienced by future generations, a process referred to as ecological inheritance (Odling-Smee et al., 2003). Soil can now be seen as niche-constructed by soil organisms. However, different biological processes occur in specific sections of it and investigations are easier to lead when parting the soil profile in three functional sub-units. 


\subsection{Why subdividing the pedon in three parts?}

The soil is the place where mineral and biological entities are joining together. The top part of the soil (Humipedon) is directly in contact with the external aerial world (aboveground plant parts and animals) while the bottom part of the soil (Lithopedon) is directly in contact with the internal mineral world; in the middle (Copedon), biological and mineral parts are interacting. The processes going on in each part are so specific that their understanding is a matter of specialists: biologists for the top, geologists or geomorphologists for the bottom and soil scientists for the middle and the whole.

In addition, these three parts of the pedon have a relatively independent way of life, giving to them a variable importance (and thickness) in the pedon. The Humipedon dominates in cold climates or hydromorphic soils, where the process of alteration of the substrate is slowly going on and the vegetation uses the soil as an organic source for its nutritional needs. The Humipedon is also dominant in temperate climates, where numerous large anecic earthworms can deeply bury organic matter, mixing it with mineral particles in a thick $A$ horizon. The Lithopedon is thicker in warm rainy climates, where the process of weathering of the parent material is rapid and vegetation uses the mineral soil as a source for its nutritional needs. The Copedon could be considered as a living bed between these two layers and if its upper and lower edges may comprehend the less organic part of the Humipedon on one side and the more altered part of the Lithopedon on the other side, it largely dominates in thickness in tropical areas where the process of rock alteration is pronounced.

The largest part of nutrient exchanges between plants and soil organisms occur in the Humipedon. The recycling of organic remains that naturally or artificially fall on the ground (litter) and are deposited directly in the soil (dead roots and root exudates) occurs in this superficial organic and organic-mineral part of the soil. Feeder roots generally occupy the Humipedon.

A series of soils that may occur in temperate regions is reported in Figure 4. A starting superficial soil begins the series, made by algae or lichens, then mosses and grasses, then passing to a deeper soil supporting a vegetation cover made of shrubs, then becoming a forest with a very deep soil.

\subsection{Humipedon and soil interdependence}

It is not a simple affair to establish soil depth or soil expansion (3D approach, or 4D with time parameter) (Richter and Markewitz, 1995). It is easier to determine the depth of the humipedon, because it corresponds to the top part of the soil, which is directly or indirectly influenced by the presence of living organisms and dead organic matter. The humipedon may be completely organic (commonly called "litter") and/or organic-mineral (A horizon), the latter being generally darker than the rest of the mineral soil. The humipedon occupies the whole soil profile in the case of organic soils (Histosols) or soils without B horizon (Entisols, AC profile soils). Functionally, and generally, the A 
horizon gradually merges in the underlying $B, E$ or $C$ horizons. In some cases, this passage may be very gradual ( $A B$ transition in many Cambisols, or $A C$ transition in superficial rocky soil).

The soil embeds the humipedon, which is smaller but more reactive to faunal and floristic changes. The humipedon registers monthly variations (Diaz-Maroto and Vila-Lameiro, 2005); while the whole soil profile formation takes centuries, or even millenaries for the most developed podzol profiles (Guillet et al., 1975) and needs decades to change in usual conditions (Dimbleby, 1952; Falsone et al., 2015). Thanks to its higher reactivity, which can be observed by naked eye at the ground surface, the humipedon may be considered as a good indicator of ecosystem health and functioning (Ponge, 2003, 2006). This is the reason we so deeply study and classify this "superficial part of the soil" instead of the whole soil profile, even if the interdependence of each horizon of a soil makes no doubt, soil horizons being pieces of a single functional unit at a higher level of organization (Agnelli et al., 2016).

Soil and ecosystem coevolution was initiated during the Devonian era, approximately 350 million years ago, when land was colonized by the first terrestrial organisms and microbes increased the concentration of carbon dioxide in the soil atmosphere, weathering underground rocks via the production of carbonic acid and releasing nutrients for subsequent root and microbial uptake (Richter and Markewitz, 1995). With these authors, we strongly believe that the overall crustal weathering process might more precisely be called biogeochemical weathering rather than geochemical weathering, due to the intensity of biological processes in weathering materials (Berthelin and Leyval, 1982). This biogeochemical transformation is concentred in the humipedon but is also present at the bottom of a deep soil profile (Richter and Markewitz, 1995).

\section{Soil and humus profiles and horizons}

Horizons. The natural soil of our planet is made of visible layers, called "horizons" because they gradually merge one into the other. Horizons are the result of an intense biological activity (by micro-, meso- and macro-organisms) which interacts with physical and chemical alterations of the mineral substrate (Fig. 5).

Soil profile $=$ side $($ commonly $100 \times 100 \mathrm{~cm})$ of a trench considered as representative of a soil (Fig. 5). Strictly speaking, the OL horizon and the R layer are not part of a newly generated soil (living organisms in a given habitat generated something new, a "soil"). In fact, soil depth is generally measured from the top of the layer of hard rock $\mathrm{R}$ ( $\operatorname{or} \mathrm{C}$, fragmented parent material, when this last is very thick) up to the limit between $\mathrm{OL}$ and OF horizons, excluding the former. However, when a soil profile is represented, all the constituent parts of the soil are shown (for the authors of this article: soil $=\mathrm{OL}$, or HF when present + newly generated soil + top part of R involved in pedogenesis). As for the definition of the pedon, dashed lines indicate top and down limits of the soil profile on Figures 2 and 5 .

Humus profile $=$ part $($ commonly $100 \times 50 \mathrm{~cm})$ of the side of a trench considered as representative of the humipedon. Notice that $\mathrm{OL}$ and $\mathrm{HF}$ horizons are always measured and investigated at the level of the humipedon. 
Humus horizon = surface organic or organic-mineral layer distinguishable from adjacent layers by a distinctive set of properties and characterized by a biogenic structure (common thickness $0.5-20 \mathrm{~cm}$, sometimes meters).

Diagnostic horizon $=$ reference for organic or organic-mineral horizons, defined by characters and qualities staying within prescribed limits; each diagnostic horizon is labelled with a code. Terrestrial horizon codes: OL, OF, OH, A; Histic horizon codes: HF, HM, HS, AH; Semi-terrestrial profiles are characterized by the presence of horizons with stagnic properties, reported by the suffix "g": gOL, gOF, gOH, gA, gAE.

Humus form = reference for a group of humus profiles displaying the same series of diagnostic horizons. Examples of terrestrial humus forms: Pachytangel, Eumesoamphi, Dysmull, Hemimoder, Eumor. Examples of Histic humus forms: Euanmoor, Oligosaprimoor, Humiamphimoor, Humimesimoor, Eufibrimoor. Examples of Semi-terrestrial humus forms: Hydro Eumull; Epihistic Euanmoor.

Humus system (abbreviation of "Humus interaction system"; interaction system as in Jagers op Akkerhuis, 2008) = reference for a group of humus profiles showing the same main characters and having nearly the same ecological determinants (biotic, mixed or abiotic) within prescribed limits. A humus system corresponds to a group of humus forms sharing globally the same mode of biological functioning (or strategy, see Ponge, 2003). This level of organization is very important for the purposes of this book and allows discerning by naked eye the features of a specific "soil functional type". Terrestrial humus systems: Tangel, Amphi, Mull, Moder, Mor. Histic humus systems: Anmoor, Saprimoor, Amphimoor, Mesimoor, Fibrimoor. Para humus systems: Anaero, Archaeo, Crusto, Bryo, Rhizo, Ligno. Anthropogenic humus systems: Agro, Techno.

The more biological part of the soil, namely the humipedon, is very important in terms of soil functioning and evolution. Soil functioning is strongly under biological influence. Pedogenesis begins at the top with organisms occupying a sterile mineral substrate. As for the composition of the air of our planet, historically and dynamically determined by the equilibrium between living producers and consumers of its molecules and elements, mineral and organic resources available in the soil are under the dependence and control of living organisms (Ponge, 2003). Among them, the most powerful in terms of energetic exchanges are microorganisms, number and variety of which still escape to a complete survey (Fierer et al., 2007). The soil is the largest source of energy and nutrients for microorganisms (Tiedje et al., 1999). All living organisms of our planet are directly or indirectly dependent from the transformations that microorganisms operate in the soil (Van der Heijden et al., 2008).

The easier way to understand soil functioning is to study the huge amount of relationships occurring in the humipedon between plants, animals and microbes (Ponge, 2013). The proposed arrangement of humipedons in a few main humus systems and forms may help better circumscribing, classifying and understanding soil functioning.

\section{In short: real objects and concepts}


To separate real objects and concepts is a crucial phase. The former are observed and described in the field; the latter are constructed in mind as imaginary references, by gathering many similar virtual objects.

\subsection{Real objects necessary for studying a humus profile}

Pedon $=$ a prism of soil of variable dimension (commonly $1 \times 1 \times 1 \mathrm{~m}$ in Europe), representing a soil in a given land. Generally, the pedon is placed in the middle of a site homogeneous in terms of vegetation, parent material and relief, or homogeneous at the ground surface, hoping the best for what cannot be seen below. Homogeneity is tested all around with a manual auger, checking for an invariant series of horizons. Field approach and observation scale are detailed in Humusica 1, articles 3 and 7 with the help of figures and sites photographs.

Soil profile $=$ a side of the prism previously occupied in the soil by a pedon .

Humipedon $=$ the upper part of a pedon made of organic and/or organic-mineral horizons.

Humus horizon = an organic or organic-mineral layer of the humipedon. Soil constituents are biologically organized into visibly, chemically, and/or physically distinct layers. Characterized by vertical discontinuities detectable by the naked eyes, the layers placed in the humipedon are referred as humus horizons. Humipedons with gradual transitions between humus horizons may define specific functional humus systems.

Humus profile $=$ the upper part of a soil profile, comprising organic and organic-mineral humus horizons.

\subsection{Concepts necessary for studying a humus profile}

Diagnostic horizon $=$ a coded description of average organic or organic-mineral horizons.

Humus form $=$ a theoretical group of humus profiles displaying the same series of diagnostic horizons.

Humus system $=$ a theoretical group of humus forms sharing biological/functional properties .

\subsection{Real objects and concepts in the field}

For observing the humipedon in the field it is necessary to dig out a cubic hole in the ground (Figs. 1b, 2 and 3), and: 
1. Facing the hole on knees, the observer cleans with a trenching tool (knife, scissor or/and pruning shear) a side of the cube $(50 \mathrm{~cm}$, sometimes $100 \mathrm{~cm}$ or more); this face is a real object called humus profile, composed of organic, organic-mineral layers of varying colour and structure (Figs. 2, 3a, 5 and 6), these real objects being called humus horizons.

2. Comparing the properties (colour, structure, texture, $\mathrm{pH} . .$. ) of humus horizons with defined properties (colour, structure, texture, $\mathrm{pH}$... within prescribed limits) of a series of diagnostic horizons (concept $=$ theoretical $=$ within prescribed limits) reported in a key of identification, the observer assigns each humus horizon to a coded diagnostic horizon (Fig. 6).

3. The defined series of diagnostic horizons and the description of the limits between them allow the observer to assign the humus profile to a particular humus form. A humus form is a concept that embraces all humus profiles displaying the same series of diagnostic horizons. A humus form is specific of a site, determined by geological, climatic, biological and historical factors.

4. Several humus forms sharing similar properties are also grouped in larger conceptual units called humus interaction systems, an expression shortened for practical reasons in humus systems (Fig. 6).

\section{Humus systems and forms classifications, historical overview}

The humus form (a specific "form = aspect" of a humus profile within a given humus system) corresponds to the part of the topsoil that is strongly influenced by organic matter and coincides with the sequence of organic $(\mathrm{OL}, \mathrm{OF}, \mathrm{OH}, \mathrm{HF}, \mathrm{HM}, \mathrm{HS})$ and underlying organic-mineral horizons $(\mathrm{A}$, $A E)$. Plant remains like leaves, needles, pieces of wood and bark, roots, root exudates, etc., form a prominent part of the primary production of forest ecosystems.

During the $19^{\text {th }}$ century, scientists noticed that the type and rate of decomposition of these organic components, as well as the incorporation of organic matter (OM) in mineral horizons, varied according to forest types. These observations led Müller (1879, 1884, translated in German in 1887 and in French in 1889, unfortunately never in English), to define three "humus forms", named Muld (later becoming Mull), Mor and Mullartiger Torf, characterized by their climatic, geological and biological conditions of formation in various Danish beech forests. From the outset, it was evident to Müller that humus forms corresponded to the "expression of life" within the topsoil. Many authors contributed to the development of a classificatory system of humus forms based on the key role of living components of the topsoil. The most prominent contributions are those of Hesselmann (1926), Hartmann (1944), Kubiëna (1953), Babel (1971) and Delecour (1983). All the concepts coined by these authors still form the basis of modern classifications (Green et al., 1993; Baize et al., 1998; Nestroy et al., 2000; Zanella et al., 2001, 2006, 2011a, b; Brunner et al., 2002; Baritz, 2003; Humusformen, 2004; Jabiol et al., 2007, 2009; Van Delft et al., 2007; AFES, 2009). Although Canadian (British Columbian) and French classifications are frequently used in an international context, none of them covers site and climate conditions worldwide, not even all European forest ecosystems. Moreover, these national classifications differ by the parameters used for describing and classifying humus forms and for scaling diagnostic parameters. Similar designations of humus forms often have different contents. With harmonization purposes in mind, a range of European specialists met in 
Trento (Italy) in 2003 and formed a European Humus Group. Improving the compatibility of established national systems of classification, a first synthesis was elaborated during the course of four plenary field sessions held in Alpine (Trento 2003, San Vito 2004, Vienna 2005) and Mediterranean (Cagliari, 2007) ecosystems. On these occasions, the place of imperfectly known terrestrial humus forms such as Tangel and Amphi and those of peat humus forms were discussed and included in a novel classification (Zanella et al., 2009).

As in previous drafts, the humus form, i.e. the part of the topsoil which is strongly influenced by biological activities and organic matter (litter included), was only partially considered, taking into account organic layers only when their thickness was very high, and ignoring many fundamental evidences necessary for a sufficiently precise characterization of forest soils, as well as of all soils not periodically ploughed. On the same year, a group of German experts proposed to adapt the most popular European and Canadian classifications of humus forms to a previous draft of WRB (Broll et al., 2006). Unfortunately, this former attempt to include humus forms in the World Reference Base failed to cover the whole range of humus forms.

Since that time, the importance given to soil/atmosphere exchanges and the destocking influence of global warming raised the importance of carbon sinks, i.e. for their main part the organic component of the soil ecosystem (Harper et al., 2007). Soil changes occurred in the past through climate warming, e.g. Podzol shifted to Cambisol, the driving force being the breakdown of organic layers (Willis et al., 1997), which means, from the point of view of humus form systematics, the evolution from a Moder to a Mull topsoil functioning (Paré et al., 2006). Climate warming imposes a biological change to organic soil horizons, resulting in a modified carbon cycle: the carbon stocked in organic layers of Moder becomes partly fixed to fine mineral particles in the newly generated organic-mineral Mull structure, the remaining part being lost as $\mathrm{CO}_{2}$. Neither the turnover rate of soil carbon nor the organic molecules in which carbon is stocked are the same when passing from Moder to Mull (Egli et al., 2009). While changes of soil main references occur over centuries (Dimbleby, 1962), decrease or increase in thickness of the forest floor occurs within decades (Bernier and Ponge, 1994), the same in semi-terrestrial environments (Delarue et al., 2011). The thorough monitoring of humus forms might thus help to reveal and foresee the impact of global warming on surfaceaccumulated organic carbon (Paré et al., 2006; Egli et al., 2009; Ponge et al., 2011), estimate the contribution of soil to atmospheric $\mathrm{CO}_{2}$ increase on a worldwide scale (Thum et al., 2011), and detect changes in hydrological environments (Bullinger-Weber et al., 2007; Sevink and De Waal, 2010), soil acidification and eutrophication (Bernier and Ponge, 1994; Pinto et al., 2007), among many other environmental threats leading to detectable changes of humus forms within a few years.

After a workshop organized in Vienna during Eurosoil 2008, and many meetings in Paris of the Classification commission of the Humus Group, a morpho-functional classification of humus forms has been proposed at the European level by Zanella et al. (2011a, b), encompassing a wide variety of humus forms, both in terrestrial and semi-terrestrial environments. Organizing the classification of humus forms in main "references" and listing soil compatible "qualifiers", Jabiol et al. (2013) published a proposal for integrating the classification of humus forms in the next WRB soil manual.

Since 2011, the Humus Group enlarged his domain of investigation and asked the contributions of ecologists, naturalists, biologists, agronomists, economists and farmers. The 
classification of humipedons involved sea-sides, high mountain ecosystems, deserts, even hot springs and tree stumps, and moved towards anthropogenic ecosystems, such as crop fields or compost piles.

\section{Present version of the key: contents, changes and innovations}

The present version of the key contents the following innovations (Fig. 7):

Concepts and real objects necessary for a clearer classification have been newly defined or better refined: humus system, humus form, humus profile, pedon, humipedon, copedon, lithopedon, humus horizon and diagnostic horizon;

Each humus system (type of process of biodegradation and consequent implementation of the litter transformation in a soil profile) is composed of 3-4 variations, called humus forms, ensuring the gradual transition towards other systems;

Humus systems are grouped in 5 different ecological units:

Terrestrial humus systems: 1 . Mull, mesophile and neutrophile humus forms; 2 . Amphi, mesophile Mediterranean, Alpine, base-rich humus forms; 3. Moder, mesophile, acidophile humus forms; 4. Tangel, cold, calcarophile humus forms; 5 . Mor cold, base-poor humus forms;

Histic humus systems: 1. Anmoor, humus forms in wet base-rich soils, small river edges, brooks, small streams and floodplains, not in dynamic floods or inundations with fast currents; 2 . Saprimoor, humus forms in wet base-rich soils, large floodplains, large extended systems partly characterized by processes of sedimentation; 3. Amphimoor, humus forms in wet moderately moist base-poor soils, in brook valley systems or base-rich soils in half-drained fens; 4 . Mesimoor, humus forms in wet moderately base-poor soils, in brook valley systems, or base-enriched soils of drained, previously base-poor fens; 5 . Fibrimoor, humus forms in wet very base-poor soils, in brook valley systems, bogs;

Transitional Terrestrial-Histic humus systems: 1. Hydro Terrestrial humus forms; 2. Epihistic Histic humus forms;

Aqueous humus systems, non-moor systems, sea sides: 1 . Tidal, humus forms in intertidal zone; 2 . Subtidal, humus forms always submerged, under the mean line of low tide;

Anthropogenic humus systems: 1. Agro, agricultural fields humus forms; 2 . Techno, manmade humus forms (e.g., composts, mulches, hydroponic solutions, dumps, mine tailings);

Para humus systems: 1. Archaeo humus system: humus forms in extremophile habitats, under the control of specialized microorganisms (archaea, algae, bacteria, cyanobacteria and fungi) forming biofilms or larger biological ecosystems; 2 . Anaero humus system: humus forms of rivers, lakes and sea beds; 3 . Crusto humus system: humus forms made by lichens, fungi, algae, cyanobacteria and crust-forming bacteria; 4 . Bryo humus system: humus forms dominated by 
mosses; 5 . Rhizo humus system: humus forms dominated by roots or rhizomes; 6 . Ligno humus system: humus forms dominated by decaying wood;

Ancient (Zanella et al., 2011; Jabiol et al., 2013) Terrestrial groups of humus forms lost in the present classification, Entiforms and Paraforms, are integrated in new Para humus systems; ancient morphofunctional Terroforms are now integrated in equivalent unchanged humus systems, except for Tangel, which passes from two to three humus forms;

Ancient Semi-terrestrial groups of humus forms lost in the present classification, Hydroforms and Epihistoforms, are transferred to new transitional units, labelled Hydro (prefix set before the name of Terrestrial systems or forms) and Epihisto (prefix set before the name of Histic systems or forms), and are considered as intergrades, Terrestrial periodically submerged humus forms and Histic periodically dried humus forms, respectively. Histoforms are now integrated in equivalent Histic humus systems. Avoiding confusion with Terrestrial humus systems all these Semi-terrestrial humus systems have their name changed, except Anmoor: Anmoor remains Anmoor, Mull becomes Saprimoor, Amphi becomes Amphimoor, Moder becomes Mesimoor, Mor becomes Fibrimoor. Ancient Semi-terrestrial Mull and Mor, now Saprimoor and Fibrimoor, respectively, pass from two to three humus forms;

Para humus systems are described and integrated in a general scheme (Fig. 7). All these Para humus systems are dynamically connected to the other humus systems in a successional way or along gradients: Crusto humus system (lichens, fungi, algae, cyanobacteria and crust-forming bacteria) may precede Bryo humus system (moss cushions), which may precede Rhizo humus system (humipedon strongly influenced by roots or rhizomes); Ligno humus forms (humipedons influenced by decaying wood) exist as islands within Terrestrial and Histic humus systems; Archaeo (topsoils in extremophile habitats) and Anaero (river, lakes and see beds, extreme Aqueous systems) are certainly linked each other and with Histo and Terro humus systems from a geological point of view.

Two anthropogenic humus systems are presented with the aim of comparing their functioning with natural references: Agro for cultivated fields, Techno for artificial manures and soils.

From the starting point in 2003, the European Humus Group thought to a non-hierarchic structure, with basic units recognisable in the field by naked eye, "easy to be detected even by naive persons". The chosen diagnostic morpho-functional humus forms properties have to reveal a relatively well-circumscribed functioning of the system that contains the soil. Humusica 1 , article 2 is dedicated to this topic. The concept of "humus interaction system", shortened in "humus system" corresponds to "morpho-functional units of soil" associated to defined series of soil horizons, which are in equilibrium with other biotic and abiotic components of a given ecosystem.

The fundamental reason for the redaction of this manual is an attempt to classify and understand the living topsoil with in mind the sustainable protection and use of the soil of our planet.

\section{General overview of humus systems and forms of planet Earth}


All humus systems have been set in a draft that looks like a spherical system (Fig. 7a): a nucleus made of 5 Terrestrial, 5 Histic plus 2 Aqueous "white circles" and 2 Anthropogenic "black circles"; "grey circles" representing the Para humus systems and "gravitating" around the others, as they do on the surface of our planet, occupying the place still not taken by non-Para main humus systems. Hydro and Epihisto semi-terrestrial intergrades are set at the centre of the figure. Terrestrial humus systems are reported with Mull humus system in the centre and two series of humus systems developing on base-poor and base-rich substrates, respectively. Histic humus systems are stretched along a line with more submerged systems on the left. Aqueous systems are in water, shared in more superficial Tidal systems and deeper Subtidal systems. Para systems can evolve into other main humus systems. Intergrades between many humus systems are well-known and the circles representing these units are partially overlapping.

Humus systems and forms are detailed in the manual. In Figure $7 \mathrm{~b}$ the ecological continuum between Histic and Terrestrial units is highlighted. Hydromorphic horizons (suffix " $\mathrm{g}$ ") characterize transitional series of humus profiles. Two prefixes allow to share transitional Histic forms from Terrestrial ones: (1) Epihistic (from Latin, Greek epi on, at, besides, after and Histic) = not typical, not deep, superficial Histic humus systems, employed as prefix when hydromorphic diagnostic horizons are present but Histic horizons dominate the humus profile; (2) Hydro (from Latin, hydro water) = "wet" Terrestrial humus systems, employed as prefix when hydromorphic diagnostic horizons are present but Terrestrial horizons dominate the humus profile.

Another view of the classification is dispatched on Figure 7c, where all Terrestrial and Histic humus systems are listed with their respective humus forms. In the present state of our knowledge, humus forms cannot be described adequately in recently disturbed environments such as wheel tracks, trampling areas, or waste dumps, i.e. everywhere some equilibrium has not been or cannot be reached between organic inputs and their processing by the soil decomposer community. This is a challenge for the future, but unfortunately still not operational.

Finding a humus form does not necessitate sophisticated instruments: a sharp knife, good eyes, and possibly a portable lens are enough. Cut the ground with a sharp knife, crossing horizons until the mineral component is clearly dominant (lighter colour). If an obstacle is encountered, repeat the operation in the vicinity, except if the obstacle is visibly a hard rock table, putting a natural limit to the observation. Recently disturbed places must be avoided, as mentioned above. According to the scale of your study, repeat your observations the number of times necessary to have a good envision of field variability: humus forms may vary at the scale of the square metre, or less, according to the heterogeneity of litter and light inputs and that of soil animal and microbial communities (Peltier et al., 2001; Kounda-Kiki et al., 2008).

\section{Authors' contribution}

A. Zanella, J.F. Ponge: coordination of authors' contributions, conception and redaction of the article, definition of basic vocabulary. 
M. Blouin, J. Juilleret, M. Aubert: development of the concept of pedon parted in three subunits.

J.M. Gobat, O. Chetov, J.L. Rubio: participation to discussions and improvement of the text.

\section{References}

AFES, 2009. Association Française pour l'Étude du Sol. Référentiel Pédologique. Quae, Paris.

Agnelli, A., Massaccesi, L., De Feudis, M., Cocco, S., Courchesne, F., Corti, G., 2016. Holm oak (Quercus ilex L.) rhizosphere affects limestone-derived soil under a multi-centennial forest. Plant Soil 400, 297-314.

Babel, U., 1971. Gliederung und Beschreibung des Humusprofils in mitteleuropäschen Wäldern. Geoderma 5, 297-324.

Baize, D., Girard, M.C., Hodgson, J.M., Eskenazi, N.R., 1998. A Sound Reference Base for Soils: The "Référentiel Pédologique" (1995). INRA Éditions, Versailles.

Baritz, R., 2003. Humus Forms in Forests of the Northern German Lowlands. Schweizertbart, Stuttgart.

Barot, S., Blouin, M., Fontaine, S., Jouquet, P., Lata, J.C., Mathieu, J., 2007. A tale of four stories: soil ecology, theory, evolution and the publication system. PLoS ONE 2, e1248.

Bernier, N., Ponge, J.F., 1994. Humus form dynamics during the sylvogenetic cycle in a mountain spruce forest. Soil Biol. Biochem. 26, 183-220.

Berthelin, J., Leyval, C., 1982. Ability of symbiotic and non-symbiotic rhizosphere microflora of maize (Zea mays) to weather micas and to promote plant growth and plant nutrition. Plant Soil 68, 369-377.

Bonduriansky, R., Day, T., 2009. Nongenetic inheritance and its evolutionary implications. Annu. Rev. Ecol. Evol. Syst. 40, 103-125.

Broll, G., Brauckmann, H.J., Overesch, M., Junge, B., Erber, C., Milbert, G., Baize, D., Nachtergaele, F., 2006. Topsoil characterization: recommendations for revision and expansion of the FAOdraft (1998) with emphasis on humus forms and biological factors. J. Plant Nutr. Soil Sci. 169, 453-461.

Brunner, H., Nievergelt, J., Peyer, K., Weisskopf, P., Zihlmann, U., 2002. Klassifikation der Böden der Schweiz. FAL-Reckenholz, Zürich.

Brussaard, L., 1997. Biodiversity and ecosystem functioning in soil. Ambio 26, 563-570. 
Bullinger-Weber, G., Le Bayon, R.C., Guenat, C., Gobat, J.M., 2007. Influence of some physicochemical and biological parameters on soil structure formation in alluvial soils. Eur. J. Soil Biol. 43, 57-70.

Certini, G., Ugolini, F.C., 2013. An updated, expanded, universal definition of soil. Geoderma 192, 378-379.

Dümig, A., Smittenberg, R., Kögel-Knabner, I., 2011. Concurrent evolution of organic and mineral components during initial soil development after retreat of the Damma glacier, Switzerland. Geoderma 163, 83-94.

Darwin, C., 1881. The Formation of Vegetable Mould through the Action of Worms, with Observations on their Habits. John Murray, London.

Delarue, F., Laggoun-Défarge, F., Buttler, A., Gogo, S., Jassey, V.E.J., Disnar, J.R., 2011. Effects of short-term ecosystem experimental warming on water-extractable organic matter in an ombrotrophic Sphagnum peatland (Le Forbonnet, France). Org. Geochem. 42, 1016-1024.

Delecour, F., 1983. Les formes d'humus: identification et description. Natural. Belg. 64, 75-86.

Diaz-Maroto, I.J., Vila-Lameiro, P., 2005. Seasonal evolution of the chemical properties and macronutrients of the soil in natural stands of Quercus robur L. in Galicia, Spain. Agrochimica 49, 201-211.

Dimbleby, G.W., 1952. Soil regeneration on the north-east Yorkshire moors. J. Ecol. 40, 331-341.

Dimbleby, G.W., 1962. The development of British heathlands and their soils. Oxf. For. Mem. 23, 150 .

Egli, M., Sartori, G., Mirabella, A., Favilli, F., Giaccai, D., Delbos, E., 2009. Effect of north and south exposure on organic matter in high Alpine soils. Geoderma 149, 124-136.

Falsone, G., Marinari, S., Vittori Antisari, L., Vianello, G., 2015. Soil processes related to organic matter modifications following Douglas-fir mature reforestation. Biol. Fertil. Soils 51, 277287.

Fierer, N., Breitbart, M., Nulton, J., Salamon, P., Lozupone, C., Jones, R., Robeson, M., Edwards, R.A., Felts, B., Rayhawk, S., Knight, R., Rohwer, F., Jackson, R.B., 2007. Metagenomic and smallsubunit rRNA analyses reveal the genetic diversity of bacteria, archaea, fungi, and viruses in soil. Appl. Environ. Microbiol. 73, 7059-7066.

GSST, 2008. Glossary of Soil Science Terms 2008. American Society of Agronomy, Madison.

Gobat, J.M., Aragno, M., Matthey, W., 2010. Le sol Vivant: Bases de Pédologie, Biologie des Sols. Presses Polytechniques Romandes, Lausanne.

Green, R.N., Trowbridge, R.L., Klinka, K., 1993. Towards a taxonomic classification of humus forms. Forest Sci. Monogr. 29, 1-49. 
Guillet, B., Rouiller, J., Souchier, B., 1975. Podzolization and clay migration in spodosols of eastern France. Geoderma 14, 223-245.

Harper, R.J., Beck, A.C., Ritson, P., Hill, M.J., Mitchell, C.D., Barrett, D.J., Smettem, K.R.J., Mann, S.S., 2007. The potential of greenhouse sinks to underwrite improved land management. Ecol. Eng. 29, 329-341.

Hartemink, A., 2016. The definition of soil since the early 1800. Adv. Agron. 137, 73-126.

Hartmann, F., 1944. Waldhumusformen. Z. Gesamt. Forstw. 76, 39-70.

Hesselmann, H., 1926. Studier över barrskogens humustäcke, dess egenskaper ochboroende av skogsvården. Medd. Stat. Skogsförsöksanst. 22.5, 1-169.

Humusformen, A.K., 2004. Systematik der Humusformen. AK Humusformen der Deutschen Bodenkundlichen Gesellschaft. Available at. http://www.humusformen.de.

ISO 10694, 1995. Soil Quality. Determination of Organic and Total Carbon After Dry Combustion (Elementary Analysis). International Organization for Standardization, Geneva.

IUSS Working Group WRB, 2006. World Reference Base for Soil Resources 2006: A Framework for International Classification, Correlation and Communication. Food and Agriculture Organization of the United Nations (FAO), Rome.

IUSS Working Group WRB, 2015. World Reference Base for Soil Resources 2014, Update 2015: International Soil Classification System for Naming Soils and Creating Legends for Soil Maps. Food and Agriculture Organization of the United Nations (FAO), Rome.

Jabiol, B., Brêthes, A., Ponge, J.F., Toutain, F., Brun, J.J., 2007. L'Humus sous toutes ses Formes, 2ème édition revue et corrigée. ENGREF, Nancy.

Jabiol, B., Brêthes, A., Brun, J.J., Ponge, J.F., Toutain, F., Zanella, A., Aubert, M., Bureau, F., 2009. Typologie des formes d'humus forestières (sous climat tempéré). In: AFES (Ed.), Référentiel Pédologique 2008. Quae, Paris, pp. 327-355.

Jabiol, B., Zanella, A., Ponge, J.F., Sartori, G., Englisch, M., Van Delft, B., De Waal, R., Le Bayon, R.C., 2013. A proposal for including humus forms in the World Reference Base for Soil Resources (WRB-FAO). Geoderma 192, 286-294.

Jagers op Akkerhuis, G.A.J.M., 2008. Analysing hierarchy in the organization of biological and physical systems. Biol. Rev. 83, 1-12.

Jenny, H., 1941. Factors of Soil Formation: a System of Quantitative Pedology. McGraw-Hill, New York.

Johnson, D.L., 1998. A universal definition of soil. Quat. Int. 51/52, 6-7.

Kounda-Kiki, C., Ponge, J.F., Mora, P., Sarthou, C., 2008. Humus profiles and successional development in a rock savanna (Nouragues inselberg, French Guiana): a micromorphological approach infers fire as a disturbance event. Pedobiologia 52, 85-95. 
Kubiëna, W.L., 1953. The Soils of Europe. Thomas Murby, London.

Lévesque, M., Dinel, H., 1977. Fiber content, particle-size distribution and some related properties of four peat materials in eastern Canada. Can. J. Soil Sci. 57, 187-195.

Lévesque, M., Dinel, H., Marcoux, R., 1980. Évaluation des critères de différentiation pour la classification de 92 matériaux tourbeux du Québec et de l'Ontario. Can. J. Soil Sci. 60, 479486.

Müller, P.E., 1879. Studier over Skovjord, som bidrag til Skovdyrkningens Theori. I. Om Bøgemuld og Bøgemor på Sand og Ler. Tidsskr. Skovbr. 3, 1-124.

Müller, P.E., 1884. Studier over Skovjord, som Bidrag til Skovdyrkningens Theori. Il. Om Muld og Mor i Egeskove og paa Heder. Tidsskr. Skovbr. 7, 1-232.

Müller, P.E., 1887. Studien über die natürlichen Humusformen und deren Einwirkung auf Vegetation und Boden. Mit analytischen Belegen von C.F.A. Tuxen. Springer, Berlin.

Müller, P.E., 1889. Recherches sur les Formes Naturelles de l'Humus et leur Influence sur la Végétation et le Sol. Berger-Levrault, Nancy.

Nestroy, O., Danneberg, O.H., Englisch, M., Gessl, A., Hager, H., Herzberger, E., Kilian, W., Nelhiebel, P., Pecina, E., Pehamberger, A., Schneider, W., Wagner, J., 2000. Systematische Gliederung der Boden Österreichs (Österreichische Bodensystematik 2000). Mitt. Österreich. Bodenkundl. Ges. 60, 1-124.

Nikol'skii, A.A., 2014. Ecological inheritance in the biological signal field of mammals. Russ. J. Ecol. 45, 76-79.

Norman, A.G., 1968. Advances in Agronomy, volume 20. Academic Press, New York.

Odling-Smee, J., Erwin, D.H., Palkovacs, E.P., Feldman, M.W., Laland, K.N., 2013. Niche construction theory: a practical guide for ecologists. Quart. Rev. Biol. 88, 3-28.

Paré, D., Boutin, R., Larocque, G.R., Raulier, F., 2006. Effect of temperature on soil organic matter decomposition in three forest biomes of eastern Canada. Can. J. Soil Sci. 86, 247-256.

Peltier, A., Ponge, J.F., Jordana, R., Ariño, A., 2001. Humus forms in Mediterranean scrublands with aleppo pine. Soil Sci. Soc. Am. J. 65, 884-896.

Pinto, P.E., Gégout, J.C., Hervé, J.C., Dhôte, J.F., 2007. Changes in environmental controls on the growth of Abies alba Mill. in the Vosges Mountains north-eastern France, during the $20^{\text {th }}$ century. Global Ecol. Biogeogr. 16, 472-484.

Ponge, J.F., Jabiol, B., Gégout, J.C., 2011. Geology and climate conditions affect more humus forms than forest canopies at large scale in temperate forests. Geoderma 162, 187-195.

Ponge, J.F., 1991. Food resources and diets of soil animals in a small area of Scots pine litter. Geoderma 49, 33-62. 
Ponge, J.F., 2003. Humus forms in terrestrial ecosystems: a framework to biodiversity. Soil Biol. Biochem. 35, 935-945.

Ponge, J.F., 2005. Emergent properties from organisms to ecosystems: towards a realistic approach. Biol. Rev. 80, 403-411.

Ponge, J.F., 2006. Humus index as an indicator of forest stand and soil properties. For. Ecol. Manage. 233, 165-175.

Ponge, J.F., 2013. Plant-soil feedbacks mediated by humus forms: a review. Soil Biol. Biochem. 57, 1048-1060.

Ponge, J.F., 2015. The soil as an ecosystem. Biol. Fert. Soils 51, 645-648.

Richter, D., Markewitz, D., 1995. How deep is soil? BioScience 45, 600-609.

Ritz, K., Young, I. (Eds.), 2011. The Architecture and Biology of Soils: Life in Inner Space. CABI, Wallingford.

Sevink, J., De Waal, R.W., 2010. Soil and humus development in driftsands. In: Fanta, J., Siepel, H. (Eds.), Inland Drift Sand Landscapes. KNNV Publishing, Zeist.

Simonson, R.W., Gardner, D.R., 1960. Concepts and function of the pedon. In: Transactions of the $7^{\text {th }}$ International Congress of Soil Science, Madison, 1960, vol. 4, pp. 127-131. Available at. http://iuss.boku.ac.at/files/7th int congress of soil science madison 1960 iv compress ed.pdf.

Soil Survey Staff, 1960. Soil Classification: a Comprehensive System, $7^{\text {th }}$ Approximation. United States Department of Agriculture, Soil Conservation Service, Washington, D.C.

Soil Survey Staff, 2014. Keys to Soil Taxonomy by Soil Survey Staff, $12^{\text {th }}$ ed. United States Department of Agriculture, Washington, D.C.

Stevenson, F.J., 1972. Role and function of humus in soil with emphasis on adsorption of herbicides and chelation of micronutrients. BioScience $22,643-650$.

Stevenson, F.J., 1994. Humus Chemistry: Genesis, Composition, Reactions, $2^{\text {nd }}$ ed. Wiley, Hoboken.

Sugden, A., Stone, R., Ash, C., 2004. Ecology in the underworld: introduction. Science 304, 1613.

Thum, T., Raisanen, P., Sevanto, S., Tuomi, M., Reick, C., Vesala, T., Raddatz, T., Aalto, T., Jarvinen, H., Altimir, N., Pilegaard, K., Nagy, Z., Rambal, S., Liski, J., 2011. Soil carbon model alternatives for ECHAM5/JSBACH climate model: evaluation and impacts on global carbon cycle estimates J. Geophys. Res. 116, G02028.

Tiedje, J.M., Asuming- Brempong, S., Nüsslein, K., Marsh, T.L., Flynn, S.J., 1999. Opening the black box of soil microbial diversity. Appl. Soil Ecol. 13, 109-122.

Ugolev, A.M., 1991. Theory of Adequate Nutrition and Trophology (in Russian). Nauka, Moscow. Available at. http://kntu-tk.narod.ru/doc/ugolev.pdf. 
Van Delft, S.J.P., De Waal, R.W., Kemmers, R., Mekkink, P., Sevink, J., 2007. Field Guide of Humus Forms: Description and Classification of Humus Forms for Ecological Applications. Alterra, Wageningen.

Van Wambeke, A., 1966. Soil bodies and soil classification. Soils Fertil. 29, 507-510.

Van der Heijden, M.G., Bardgett, R.D., Van Straalen, N.M., 2008. The unseen majority: soil microbes as drivers of plant diversity and productivity in terrestrial ecosystems. Ecol. Lett. 11, 296310 .

Willis, K.J., Braun, M., Sümegi, P., Tóth, A., 1997. Does soil change cause vegetation change or vice versa: a temporal perspective from Hungary. Ecology 78, 740-750.

Zanella, A., Tomasi, M., de Siena, C., Frizzera, L., Nicolini, G., Sartori, G., Calabrese, M.S., Mancabelli, A., Nardi, S., Pizzeghello, D., Odasso, M., 2001. Humus Forestali. Centro di Ecologia Alpina, Trento.

Zanella, A., Englisch, M., Jabiol, B., Katzensteiner, K., De Waal, R., Hager, H., Van Delft, B., Graefe, U., Brun, J.J., Chersich, S., Broll, G., Kolb, E., Baier, R., Baritz, R., Langohr, R., Cools, N., Wresowar, M., Milbert, G., Ponge, J.F., 2006. Towards a common humus form classification, a first European approach: few generic top soil references as functional units. Poster presented at the $18^{\text {th }}$ World Congress of Soil Science, Philadelphia, July 9-15, 2006. Available at https://www.researchgate.net/publication/280522787.

Zanella, A., Jabiol, B., Ponge, J.F., Sartori, G., De Waal, R., Van Delft, B., Graefe, U., Cool, N., Katzensteiner, K., Hager, H., Englisch, M., Brêthes, A., 2009. Toward a European humus forms reference base. Studi Trent. Sci. Natur. 85, 145-151.

Zanella, A., Jabiol, B., Ponge, J.F., Sartori, G., De Waal, R., Van Delft, B., Graefe, U., Cools, N., Katzensteiner, K., Hager, H., Englisch, M., 2011a. A European morpho-functional classification of humus forms. Geoderma 164, 138-145.

Zanella, A., Jabiol, B., Ponge, J.F., Sartori, G., De Waal, R., Van Delft, B., Graefe, U., Cools, N., Katzensteiner, K., Hager, H., Englisch, M., Brêthes, A., Broll, G., Gobat, J.M., Brun, J.J., Milbert, G., Kolb, E., Wolf, U., Frizzera, L., Galvan, P., Koli, R., Baritz, R., Kemmers, R., Vacca, A., Serra, G., Banas, D., Garlato, A., Chersich, S., Klimo, E., Langohr, R., 2011b. European Humus Forms Reference Base. Available at http://hal.archivesouvertes.fr/docs/00/56/17/95/PDF/Humus Forms ERB 3101 2011.pdf.

Zanella, A., 1994. Entropie et évolution des systèmes naturels, la cascade inversée. In: Zanella, A. (Ed.), Proposition pour une Typologie Forestière Intégrée: Exemples d'Application aux Forêts de la Flandre Française Intérieure. Doctoral dissertation, Université de Paris 11, Orsay, pp. 173-177. 


\section{Figure captions}

Fig. 1. (a) "For living you have to die" is a strong and thus provocative phrase. Life is based on a foodchain-concept. Nothing is more interdependent than death and life. A process of matter recycling is necessary for every ecosystem evolution. Biodegraded/decomposed/digested organisms furnish bricks for building new organisms, new life. Thus, the process of death is strictly interrelated to that of birth. A large part of this process occurs in the soil (have we a soil in our belly?). In a context of climate change, to take a rest for a short philosophic reflection about the real meaning of co-evolution and life, is not a bad idea. (b) The pedon is a column representing the soil in a given part of the land. A pedon is generally studied by observing the sides of the prismatic hole created in the ground for extracting it. In case of deep soil, the hole will be large enough for containing the observer.

Fig. 2. Pedon horizons and sub-units: (a) main horizons in aerated soils; (b) main horizons in submerged soils; (c) Pedon sub-units: Humipedon, Copedon and Lithopedon.

Fig. 3. Humus profiles: (a) profile of an acid Terrestrial soil, in a spruce forest (Parco dei Sogni, Lorenzago, Italy). The side of the hole made in the ground that shows the succession of different horizons is called "humus profile". The dark part of the profile, studied by humus specialists, is here evident and occupies the first top $20 \mathrm{~cm}$. The humus system is a Moder and the humus form a Dysmoder (the humipedon classification key is presented in Humusica 1, article 4); b) profile of a neutral Histic soil, on the shore of an artificial lake (Paimpont, France). The humus system is an Anmoor and the humus form a Euanmoor. Opening the soil to a depth of $30 \mathrm{~cm}$ is generally sufficient for unearthing and classifying the "dark part of the soil", a volume occupied by a series of organic and organic-mineral layers overall called "humipedon".

Fig. 4. A simplified chronosequence of soils showing how the number of soil horizons increases with time and depth. The process illustrated is not linear and may take several centuries for transforming a hard rock into a common Cambisol (Dümig et al., 2011). In addition of living organisms, a Humipedon is made of organic $\mathrm{O}$ (litter and transformed litter) and organicmineral A horizons, the latter generally collapsing in a mineral $\mathrm{C}$ horizon in the first phases of soil formation. In many soil classifications, fresh litter is still not considered as soil. In this manual, the litter is a component of the soil. Generally, Humipedon, Copedon and Lithopedon do not take place at the same time. Bacteria are everywhere and colonise even bare rock. They can start the process of formation of a humus system on hard or fragmented rock. A very thin quite invisible organic Humipedon begins the series (Crusto systems are described in Humusica 2, article 13). The Copedon takes place in a second time as a developing junction that slowly becomes thicker and acquires a certain independence of functioning, thanks to a formation of new very active particles of clay. A depth of $2 \mathrm{~m}$ is considered as the lower limit in general international soil classification. In this manual, we focused on the Humipedon which rises an average depth of $30 \mathrm{~cm}$ in forest ecosystems and grasslands, subsiding even many metres in Histic (peats) ecosystems.

Fig. 5. Illustrated vocabulary for soil and humus survey. a) Real objects: Pedon, Soil profile, Humus profile, Humus horizons. Concepts: Humipedon, Copedon, Lithopedon; Diagnostic horizons. Pedon and its subdivisions; b) Soil and humus profiles in a pedon and a humus profile in a 
Humipedon from a Luxembourgian beech forest; humus profile subdivided in humus horizons; humus system: Amphi. Concepts (theoretical references): Humus diagnostic horizons, Humus system subdivided in Humus forms.

Fig. 6. I got it. Real objects (humus profiles and humus horizons) and concepts (humus systems and humus forms). Field operations: (1) open a hole in the ground; (2) detect humus horizons; (3) assign each horizon to a theoretical reference, called diagnostic horizon; (4) assign the series of diagnostic horizons to a theoretical humus system; (5) within the humus system, when possible, individuate the detailed theoretical humus form. "Theoretical reference" means a construction of the human mind which groups real objects having some properties in common. These references allow simplifying the real world and better understanding the unlimited variety of natural processes.

Fig. 7. (a) Structure of the classification of humus systems: 12 Main humus systems (white in the centre: 5 Terrestrial systems: Mull, Moder, Mor, Amphi Tangel; 5 Histic: Fibrimoor, Mesimoor, Amphimoor, Saprimoor, Anmoor; 2 Aqueous systems: Tidal and Ssubtidal) +2 Anthropogenic systems (black: Agro and Techno) and 6 Para systems as grey "satellites" (Archaeo, Anaero, Rhizo, Crusto, Bryo, Ligno). (Authors: A. Zanella, J.F. Ponge, C. Ferronato, M. De Nobili). (b) Overview of relationships between Terrestrial, Histic, and Aqueous humus systems and forms. Illustration of the ecological continuum between Aqueous, Histic and Terrestrial systems (Authors: A. Zanella, J.F. Ponge, C. Ferronato, M. De Nobili). (c) Overview of the relationships between Terrestrial, Histic, Para and Anthropogenic humus systems and forms. View of the whole system of classification with 5 Terrestrial humus systems subdivided in 18 humus forms, 5 Histic humus systems subdivided in 16 humus forms, 6 Para and 2 Antropogenic humus systems. 

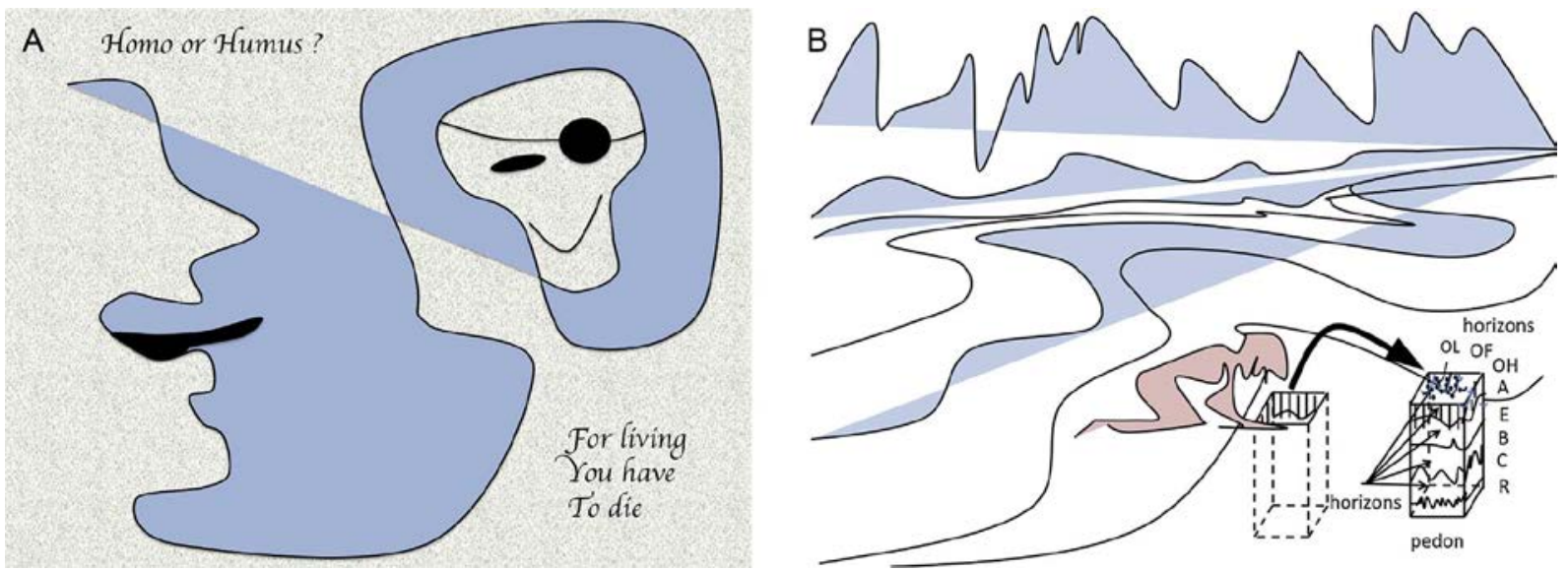

Fig. 1 


\section{${ }^{\text {A AERATED SOILS }}$}

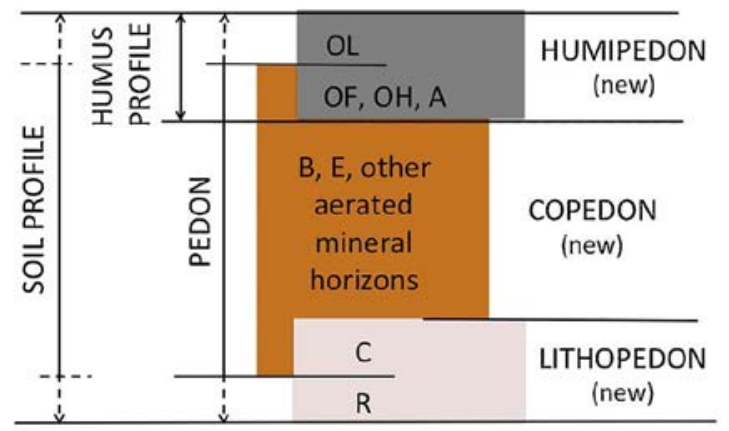

C

\section{${ }^{B}$ SUBMERSED SOILS}

\begin{tabular}{|c|c|c|c|}
\hline \multirow{3}{*}{ 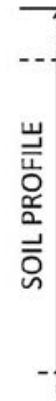 } & 象岸 & $\frac{H F}{H M, H S}$, anA & $\begin{array}{l}\text { HUMIPEDON } \\
\text { (new) }\end{array}$ \\
\hline & 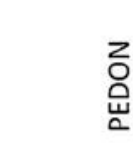 & $\begin{array}{l}\mathrm{Bg} \text {, Eg, L, other } \\
\text { anoxic or } \\
\text { hydromorphic } \\
\text { horizons }\end{array}$ & $\begin{array}{c}\text { COPEDON } \\
\text { (new) }\end{array}$ \\
\hline & & $\frac{\mathrm{Cg}}{\mathrm{R}}$ & $\begin{array}{c}\text { LITHOPEDON } \\
\text { (new) }\end{array}$ \\
\hline
\end{tabular}
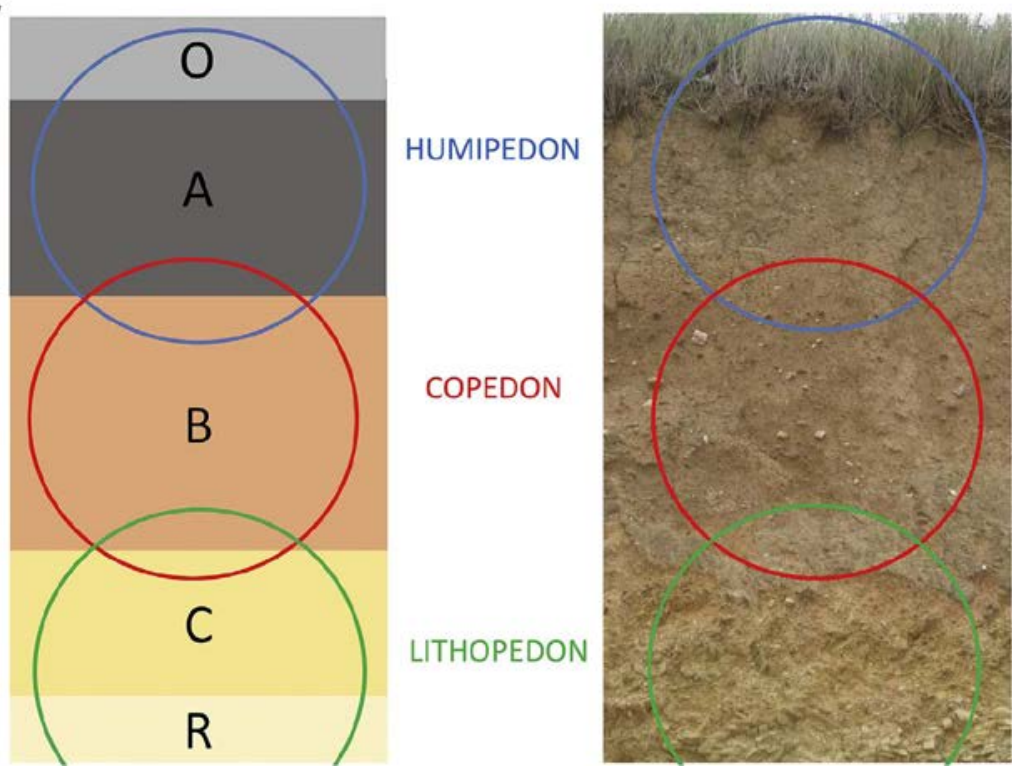

Fig. 2 

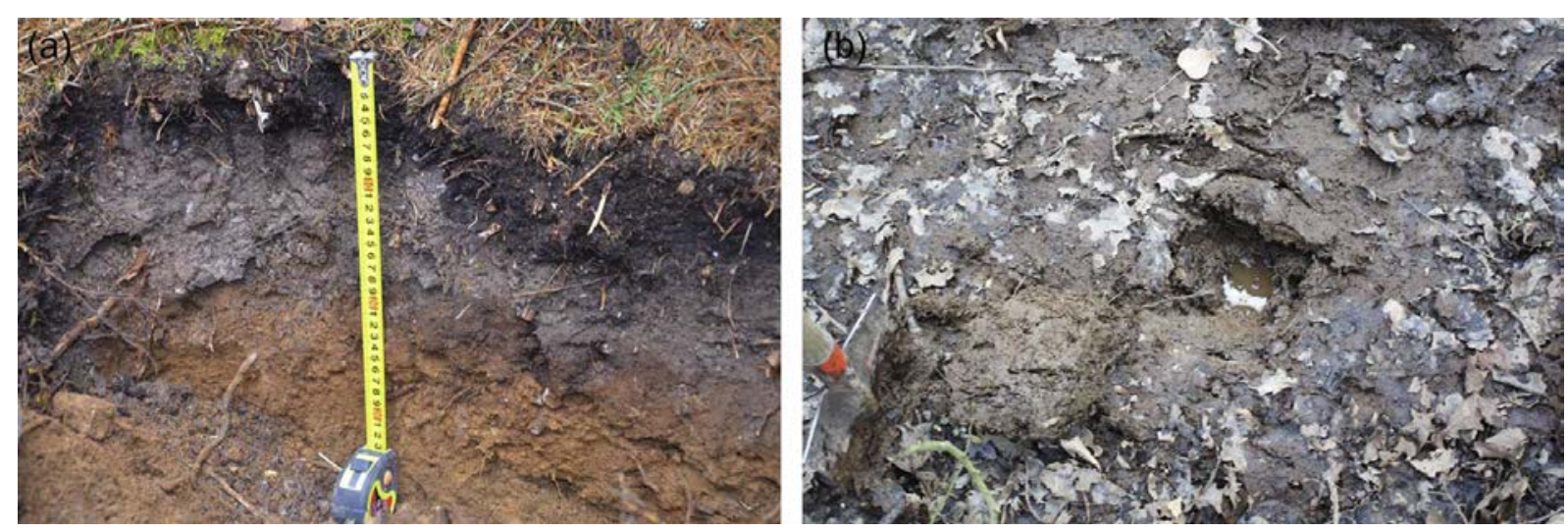

Fig. 3 


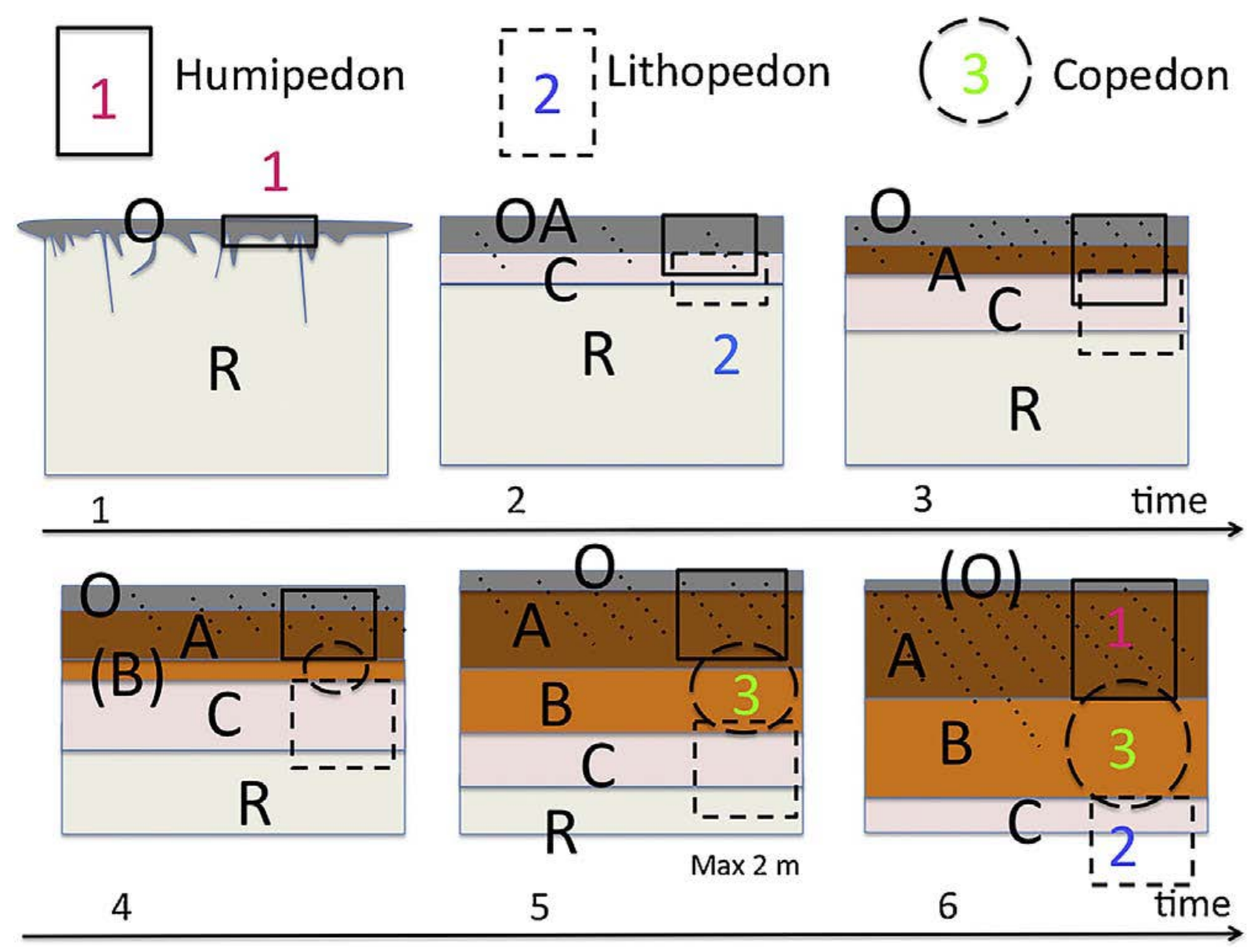

Fig. 4 

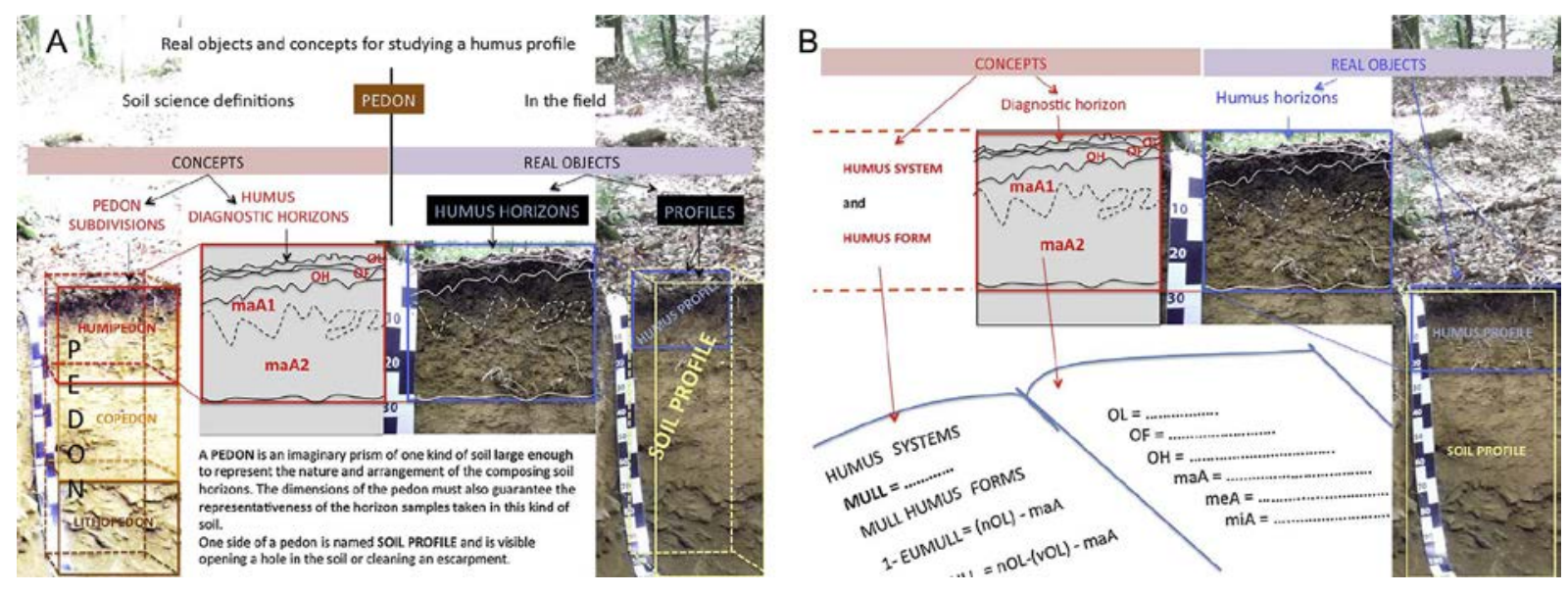

Fig. 5 
31

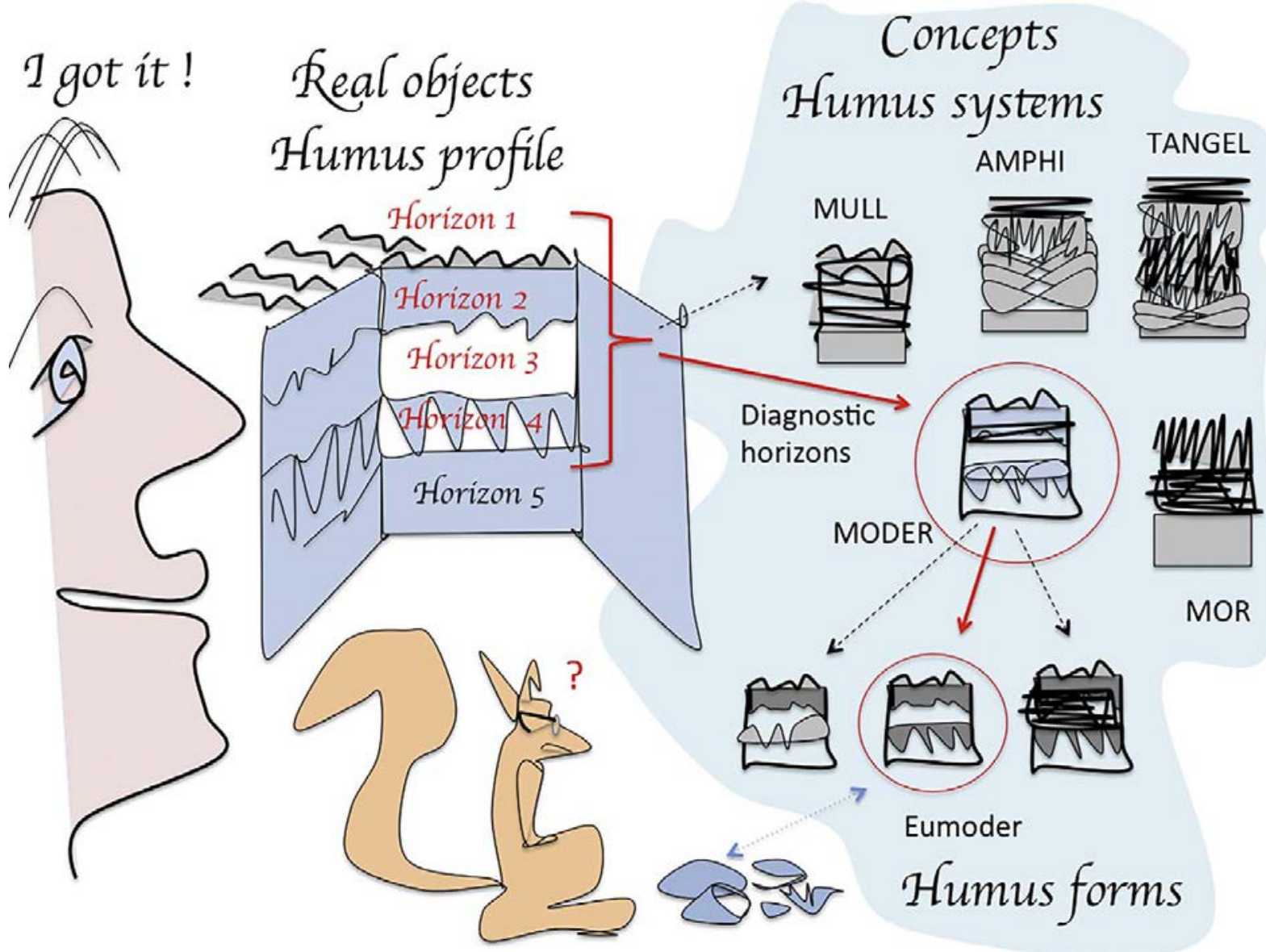

Fig. 6 
A

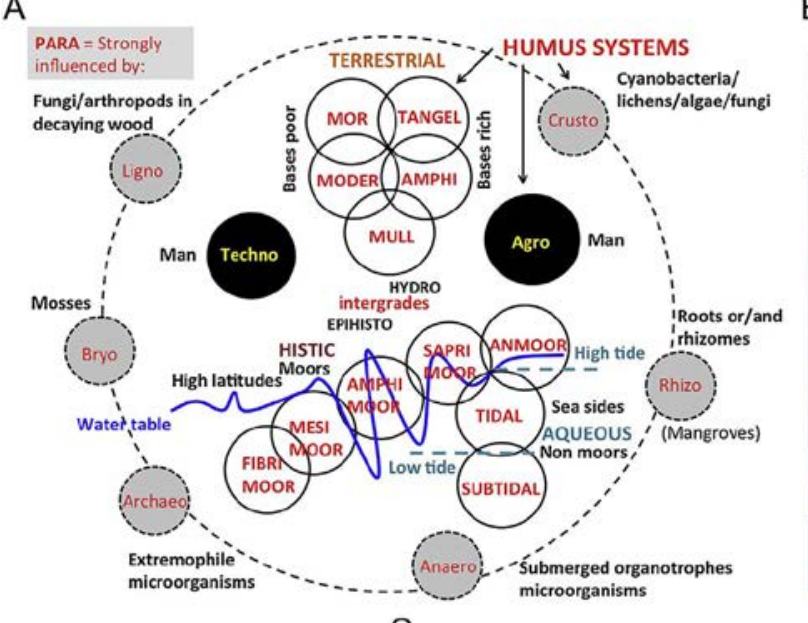

B

HISTIC (Moors)

Humus forms in which faunal activities and

decomposition of organic matter are well

visible but are or have been strongly limited

and/or influenced by anaerobic conditions

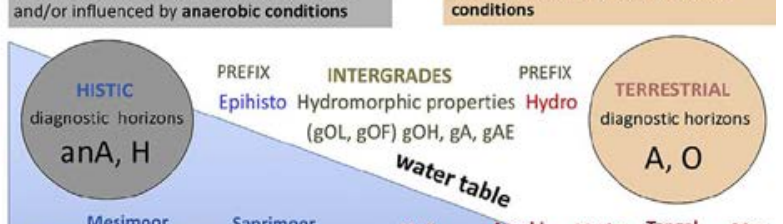

Mesimoor Saprimoor Fibrimoor I Amphimoor Anmoor Mull Amphi Moder Tangel Mor

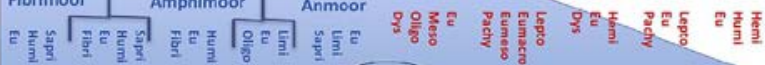

AQUEOUS (Non Moors) AQUEOUS

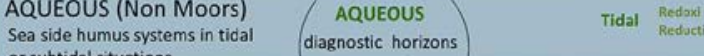
characterized by organic-mineral anaA suberats redoximorphic horizons

C

TERRESTRIAL
Humus forms whose faunal activities and
decompostion of forganic matter are well visible
and occur in aerated concitions

Fig. 7 